\title{
ブレース付架構制振装置のオンライン・コンピュータ制御 地震応答実験 \\ A COMPUTER-ACTUATOR ON-LINE TEST OF HYSTERETIC DAMPING DEVICE INSTALLED IN BRACED FRAME UNDER STRONG EARTHQUAKES
}

\author{
玉井宏章*, 近藤一夫**, 花井正実*** \\ Hiroyuki TAMAI, Kazuo KONDOH and Masami HANAI
}

\begin{abstract}
A computer-actuator on-line test of the braced frame with the hysteretic damping device proposed in the author's previous papers, which needs no assumptions for the restoring forces of structures and so that, is one of the most promising approaches to trace the elasto-plastic behaviors and especially fracture process of structures, is presented.

Outline of the present test system is summarized, in which new, effective error correction procedures are employed in order to eliminate the difference between computed and actually measured displacements, often called as the "displacement control-error", and its accuracies are verified by simple Single-Degree-Of-Freedom (S. D. O. F. ) elastic response tests.

Based on these verification tests, a series of S.D.O.F. elasto-plastic response tests to the earthquake ground motions are performed.

Also, after the restoring force characteristic of the hysteretic damping device in the test being idealized to two numerical models, which are of the bi-linear and the Ramberg-Osgood's type respectively, the accuracies and the validities of these models in the earthquake response analyses are clarified by comparing with the experimental results.
\end{abstract}

Keywords : Hysteretic Damping Device, On-line Test.

\section{1. 序}

建築架構ブレースの中央交叉部に，有孔鋼板と四角形 に連結した連結材とからなる履歴娍衰装置を配置した機 構は, 激震時に 2 本のブレースに交互に加わる引張力に より, 有孔鋼板が塑性変形して, 紡鍾状の荷重-変形履 歴特性を持ち，大きなエネルギ一吸収が行われるので， 制振装置として有効であることが,これまでの研究で明 らかとなった11.2)。この装置を用いて耐震設計を実際に 行うには，この装置を設置した建物の地震時の安全性を 十分確認しておくことが求められる。そのためには, 構 造部材の地震時における履歴特性や極低サイクル疲労特 性等についても明確にしておく必要があり, 単なる建物 の地震応答解析のみでは安全性が確保されたとは言い難 い。このような観点から, 著者らは, 既に, 履歴減衰装 置の定振幅繰り返し実験等により，定振幅時の履歴特性， 極低サイクル疲労特性等を明らかにしている2。
本研究では，これらの特性に基づいて，建物の実地震 応答についてのオンライン・コンピュータ制御実験? を 行い, 1) 本制振装置の実地震応答時におけるエネルギー 吸収性能, 非定常振幅疲労特性を明らかにするとともに， 2）履歴娍衰装置の復元力を解析モデルに置き換えた数 値解析結果と実験結果とを比較，検討することにより， 数值復元力モデルの精度，有用性を検討する。また，3） 弾塑性地震応答実験から求まった変位応答時刻歴を用い た非定常振幅疲労試験を行い，定常振幅疲労試験結果お よび 2 段 2 重疲労試験結果を基に，地震荷重下において も線形累積損傷則が成立するかどうかを検証する。さら に，4）これらの結果を基に，種々の構造特性を持つ建 物が 2,3 の地震波を受けた場合の実地震応答解析を行 い，実地震時の制振装置の累積損傷値等についても明ら かにする。

本報は，その第 1 報であり，本研究で採用した実験シ

本報告の一部は文献 3），4）に既に発表している。

*広島大学 助手. 工修

**広島大学 助教授. 工博

***広島大学 教授.工博

Research associate of Hiroshima Univ. Associate Prof. of Hiroshima Univ., Dr. Eng.

Prof. of Hiroshima Univ., Dr. Eng. 
ステムの概要について述べるとともに，その精度が十分 良好なものであることをいくつかの弾性振動実験によ り, 検証する。その際,この種の実験で最も問題となる 試験機の位置决め誤差をなくす方法の提案を行い，その 有効性を明らかにする。また, 履歴減衰装置の復元力特 性を，漸増振幅試験結果を基にBi-linear 型および Ramberg-Osgood 型に近似し，その実地震応答性状を 実験結果と比較することにより, 数值復元力モデルの精 度, 有用性を検討する。

\section{2. 架構のモデル化と運動方程式}

2.1. 制振装置付ブレース架構のモデル化と運動方程 式

振動モデルは, 制振装置が設置された中低層鉄骨ブ レース付架構を想定し, Fig. 1(a) に示す水平方向自由 度のみを有するせん断型の多質点系とする。質量比例型 の減衰を仮定すると, この振動モデルの運動方程式は次 式のように表される。

$$
m \cdot \ddot{x}+c \cdot \dot{x}+f=-m \cdot I \cdot \ddot{y} \cdot
$$
ここに,

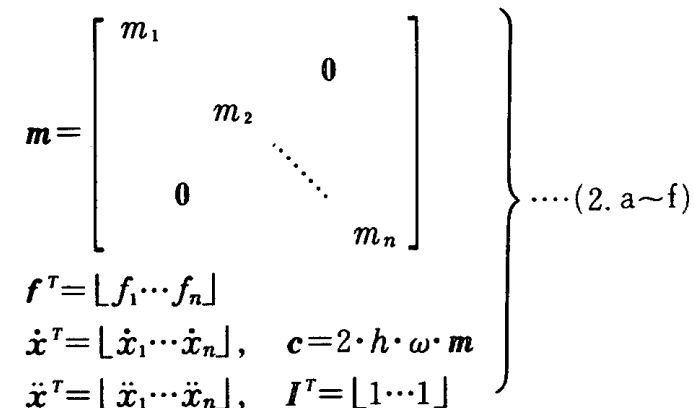

$m_{i}: i$ 質点の質量

$\ddot{y}:$ 地動加速度

$\dot{x}_{i}: i$ 質点の速度

$\omega:$ 系の基本固有振動数

$\ddot{x}_{i}: i$ 質点の加速度

$h$ : 減衰定数

$f_{i}: i$ 質点の復元力

復元力ベクトル：fは, Fig. 1(b) に示す制振装置を組 み込んだピン節トラスの復元力と, 曲げ抵抗型のフレー ムの復元力の和として次式のように表される。

$$
\boldsymbol{f}=\boldsymbol{f}_{f}+\boldsymbol{f}_{d}
$$

ここに,

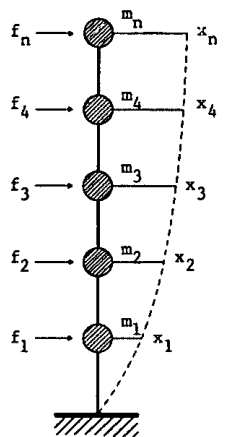

(a)

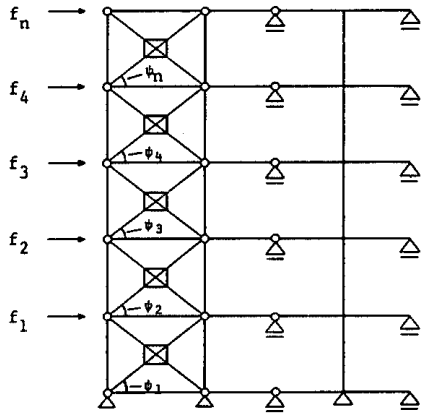

(b)
Fig. 1 Model for analyzing braced frame

$$
\begin{aligned}
& \boldsymbol{f}_{f}^{T}=\left\lfloor f_{f, i} \cdots f_{s, n}\right\rfloor \\
& \boldsymbol{f}_{d}^{\tau}=\left\lfloor f_{d, i} \cdots f_{d, n}\right\rfloor
\end{aligned}
$$

$f_{f, i}: i$ 質点のフレームの復元力

$f_{d, i}: i$ 質点の制振装置の復元力

であり、フレームが弾性の場合には，ffl，次式となる。

$$
f_{f}=k_{f} \cdot x
$$

ここに

$k_{f}$ : 水平方向自由度のみに縮約したフレームの弾性㴊

性マトリックス

$$
x^{r}=\left\lfloor x_{1} \cdots x_{n}\right\rfloor \cdots
$$

$x_{i}: i$ 質点の変位

一方, 减衰装置を組み込んだトラスの復元力： $f_{d, i}^{\prime}$ は, 次式のように表される。

$$
\begin{aligned}
& f_{d, i}=Q_{d, i}-Q_{d, i+1} \\
& Q_{d, i}=n_{d} \cdot \hat{Q}_{d, i} \cdots \\
& \hat{Q}_{d, i}=\hat{P}_{i} \cdot \cos \Psi_{i}
\end{aligned}
$$

ここに,

$Q_{\boldsymbol{d}, i}: i$ 層の制振装置の分担せん断力

$n_{d}$ : 一層当たりの制振装置の設置数

$\hat{Q}_{d, i}$ : 制振装置一体当たりの分担せん断力

$\hat{P}_{i}:$ ブレースを介して履歴減衰装置に負荷される力

$\Psi_{i}: i$ 層のブレースの仰角

また，ブレース方向の層間変位量からブレースの伸び 量を差し引いた形で表される履歴減衰装置のピン間相対 変位： $\delta_{s, i}$ は, ブレースは弾性範囲内にとどまるものと すると，次式となる。

$$
\delta_{s, i}=\Delta_{i} \cdot \cos \Psi_{i}-\hat{P}_{i} \cdot \frac{l_{d, i}}{E \cdot A_{d, i}}
$$

ここに,

$$
\Delta_{i}=x_{i}-x_{i-1}
$$

$\Delta_{i}: i$ 層の層間変位

$$
E: \text { ヤング率 }
$$

$A_{c h i}: i$ 層のブレース断面積 $\quad l_{d, i}: i$ 層のブレース長 $(5 . \mathrm{a} \sim \mathrm{c})$ 式および $(6 . \mathrm{a}, \mathrm{b})$ 式より，履歴減衰装置の $\hat{P}_{i}-\delta_{s, i}$ 関係が実験的に, あるいは数值モデルとして与 えられれば,トラスの復元力は定まる。

なお，本研究は，前述のように，多層の制振ブレース 付架構の地震動に対する特性を調べることを目的として いるが，オンライン・コンピュー夕制御実験としては, ある特定の一層についてのみ $\hat{P}_{i}-\delta_{s, i}$ 関係を求めるため の実験を行い, ほかの層については, 単層の実験結果か ら, 各層の復元力特性が, 十分な精度で, 数值モデルで 置き換えられるものとして, 次節に示す数值モデルを朋 いている。また, 実験は, 実大の履歴減衰装置を数分の 1 に縮小したモデルについて行っており，いま，実大の 有孔鋼板に対する実験に供した有孔鋼板の幅および厚さ の縮小率を，それぞれ，(1/a $)$ および $\left(1 / a_{t}\right)$ 之すると $\hat{P}_{i}, \delta_{s, i}$ は，それぞれ，次式のように与えられる。

$$
\hat{P}_{t}=a_{w} \cdot a_{t} \cdot \tilde{P}_{t}
$$




$$
\delta_{s, i}=\alpha_{w} \cdot \tilde{\delta}_{s, i}
$$

ここに,

$\tilde{P}_{t}$ : 実験に供した履歴減衰装置に負荷した荷重

$\tilde{\delta}_{s, \iota}$ : 実験に供した履歴減衰装置のピン間相対変位

2.2 履歴减衰装置の復元力モデル

文献 2）に示したように，板中央の角型孔のほかに， 中央孔を囲むように 8 個の榇円孔を配した有孔鋼板は, 安定した紡錘型の履歴特性を示し，耐力低下を起こすま での吸収エネルギーも大きい。本研究では, 履歴減衰装 置に用いる有孔鋼板としてこの形式のものを用いること とし，まず，その復元力特性をより詳細に調べるために， S 1 LM (文献 2) 参照) の形状の有孔鋼板について, ピン間相対変位振幅を $0.1(\mathrm{~cm}) \cdot$ から $0.8(\mathrm{~cm})$ まで $0.1(\mathrm{~cm})$ ずつ漸増させ, 各振幅レンジで 2 サイクル繰

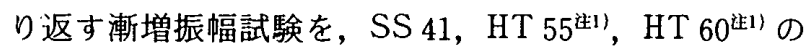
3 種の鋼材について行った。実験装置, 計測装置等につ いては，文献1）を参照されたい。

Fig. 2 は, 各振幅レンジでの 2 サイクル目の荷重 : $\tilde{P}$ とピン間相対変位: $\tilde{\delta}_{s}$ との関係を示したものであり,
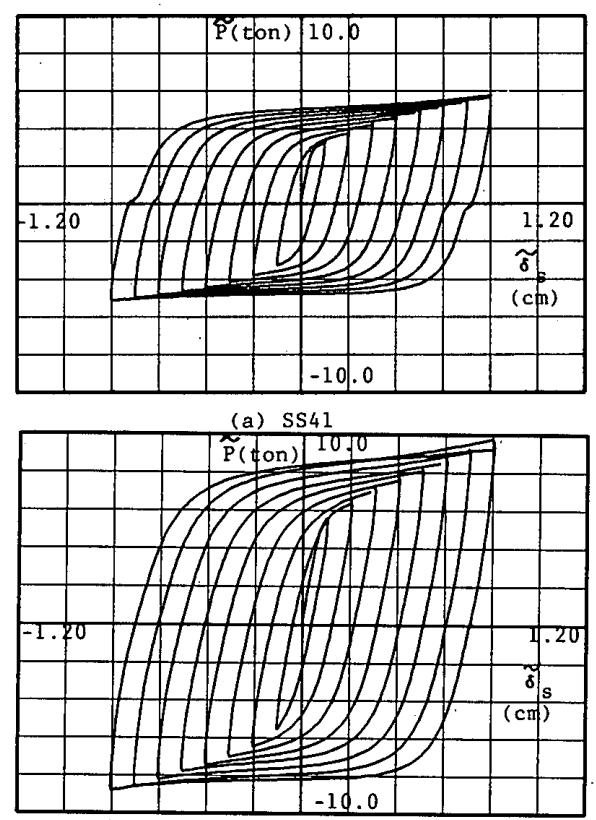

(b) HT55

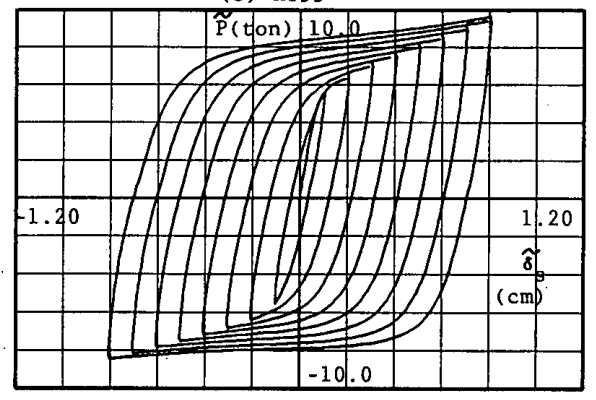

(c) $\mathrm{HT} 60$

Fig. $2 \tilde{P}-\tilde{\delta}_{s}$ relationship of S $1 \mathrm{LM}$

注 1），HT 55 およびHT 60 は，NKK 規格であり，それぞれ， SPV 36 および SM 58 相当品である。
いずれの場合についても，履歴減衰装置は，履歴吸収工 ネルギーの大きい安定した紡鍾型の復元力特性を有する こと，また，大きなピン間相対変位振幅に対しても，耐 力低下はほとんど生じないことがわかる。

この実験結果に基づき，本研究では，履歴減衰装置の 復元力特性を表す数值モデルとして，以下に示す方法に より定めた Bi-linear 型と Ramberg-Osgood 型の 2 つの ものを採用することとし，その骨格曲線，履歴特性およ び特性值を, 実験結果および素材特性值とともに,

Fig. 3(a,b) およびTable 1に示す。

○Bi-linear 型復元力モデル

Bi-linear 型の復元力モデルは, 弾性限耐力 : $\tilde{P}_{\boldsymbol{y}}$, 弾 性限ピン間相対変位: $\tilde{\delta}_{s y}$ および降伏後の剛性 $: K_{s 2}^{*}$ が 求まれば，一義的に定まる。

本研究では, $\tilde{P}_{y}$ と $\tilde{\delta}_{s y}$ は, FEM 解析 ${ }^{\prime}$ により求めた 弾性時の荷重一ピン間相対変位関係と, 先に示した漸増 振幅試験により得られた荷重振幅-ピン間相対変位振幅 関係を最小 2 乗近似した直線との交点の值を採用し，一 方， $K_{s 2}^{*}$ は，最小 2 乗近似直線のこう配とした。

ORamberg-Osgood 型復元力モデル

次に, Ramberg-Osgood 型の復元力特性は, 文献 9)に

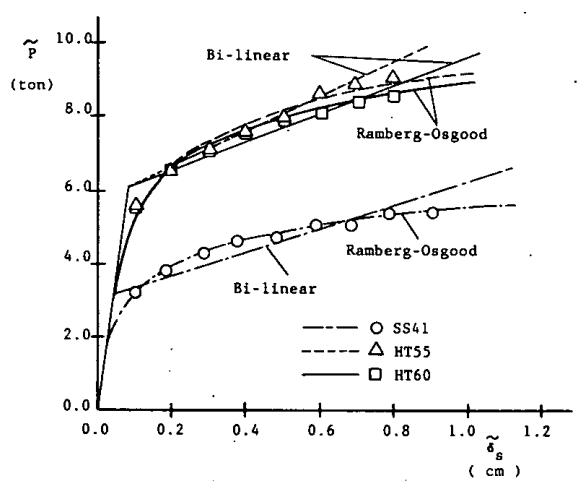

Fig. 3(a) Skeleton curves of damping devices

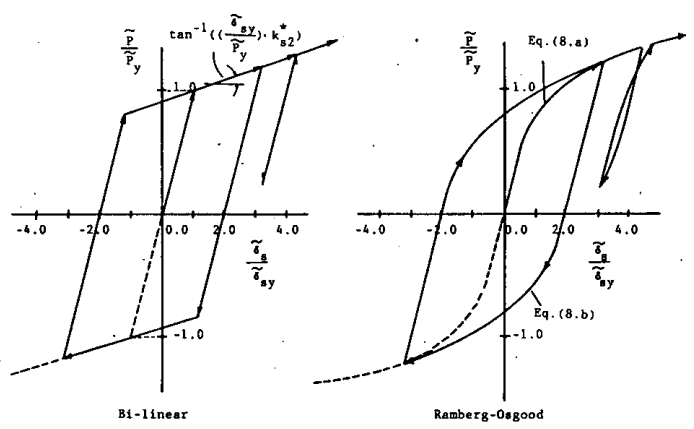

Fig. 3(b) Two types of assumed hysteresis of damping device

Table 1 Mechanical properties of hysteretic damping devices

\begin{tabular}{|c|c|c|c|c|c|c|c|c|c|}
\hline & $\begin{array}{l}\widetilde{\mathbb{P}_{y}} \\
(t)\end{array}$ & $\begin{array}{l}\widetilde{\mathrm{b}}_{\mathrm{sy}} \\
(\mathrm{cm})\end{array}$ & $\begin{array}{c}\mathrm{K}_{\mathrm{s} 2}^{*} \\
(\mathrm{t} / \mathrm{cm})\end{array}$ & a & b & $\begin{array}{c}{ }^{y} \\
\left(t / \mathrm{cm}^{2}\right)\end{array}$ & ${ }_{\left(\mathrm{a} / \mathrm{cm}^{2}\right)}$ & $\begin{array}{c}\varepsilon \\
(z)^{u}\end{array}$ & $\begin{array}{c}\mathrm{E}_{\mathrm{st}} \\
(\mathrm{t} / \mathrm{cm})\end{array}$ \\
\hline SS41 & 3.330 & 0.04838 & 3.077 & 5.4345 & 1.1992 & 2.97 & 4.36 & 24.12 & 32.23 \\
\hline HT55 & 6.031 & 0.08762 & 4.800 & 6.7769 & 0.5964 & 5.09 & 6.37 & 29.35 & 32.98 \\
\hline HT60 & 6.062 & 0.08807 & 4.225 & 7.5048 & 0.6108 & 5.32 & 6.42 & 31.51 & 26.40 \\
\hline
\end{tabular}




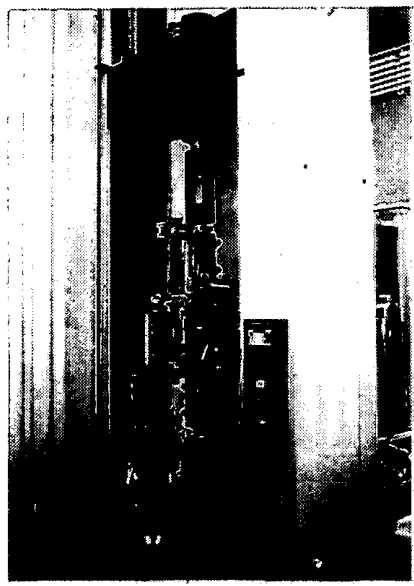

(a) Actuator

Photo. 1 Computer-actuator on-line test system

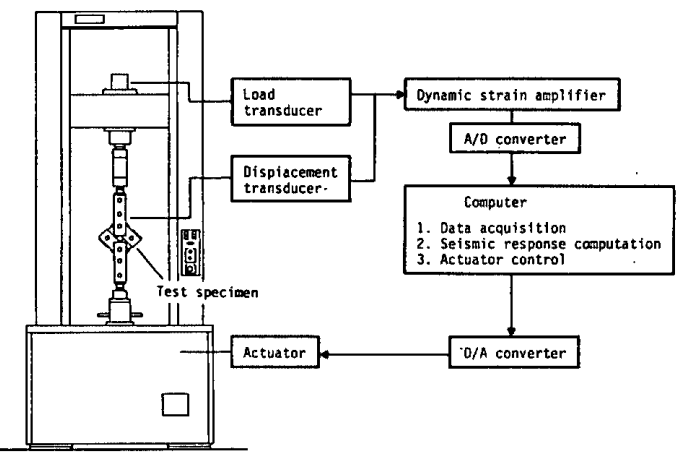

Fig. 4 Computer-acturator on-line test system

従い，次のように定めた。

骨格曲線を,

$$
\frac{\tilde{\delta}_{s}}{\tilde{\delta}_{s y}}=\frac{\tilde{P}}{\tilde{P}_{y}} \cdot\left(1+b \cdot\left|\frac{\tilde{P}}{\tilde{P}_{y}}\right|^{a-1}\right)
$$

とし, また, 載荷方向が逆転したときの履歴曲線は, 反 転時の荷重: $\tilde{P}_{r}$, ピン間相対変位 $: \tilde{\delta}_{s r}$ を用いて,

$$
\frac{\tilde{\delta}_{s}-\tilde{\delta}_{s r}}{2 \cdot \tilde{\delta}_{s y}}=\frac{\tilde{P}-\tilde{P}_{r}}{2 \cdot \tilde{P}_{y}} \cdot\left(1+b \cdot\left|\frac{\tilde{P}-\tilde{P}_{r}}{2 \cdot \tilde{P}_{y}}\right|^{a-1}\right)
$$

とする。

$\tilde{\delta}_{s y}, \tilde{P}_{y}$ は, Bi-linear 型復元力モデルで定めた弾性限 ピン間相対変位および弾性限荷重の值を採用し，また, 定数 $a, b$ は, 漸増振幅試験より得られた荷重振幅一ピ ン間相対変位振幅関係を(8.a) 式により最小 2 乗近似 することにより定めた。なお，(8.b) 式で与えられる 履歴曲線は, 過去に経験した最大および最小荷重点から の履歴曲線を越えないものとし,それらと交わった後は, 最大および最小荷重点からの履歴曲線上を動くものとし た。

\section{3. 実験システムの概要}

次に，本研究で用いたオンライン・コンピュー夕制御 実験システムについて報告する。

\section{1 実験装置}

実験装置の概要をFig. 4 および Photo: 1 に示す。試
験体は，有孔鋼板と八枚の連結材およびそ れらを接合するピンとからなる履歷减衰装 置を，ガイドプレートで挟み，その上下に ネジ式のジョイントを高力ボルトで取り付 けたものであり, 加力装置とは上下のジョ イントを介して接合されている。試験体の 上下方向に圧縮力と引張力が作用すると, 連結材の連結作用により，有孔鋼板には， 上下, 左右のピンから交互に, 圧縮力と引 張力が作用することになる。変位の計測は, 上下および左右の対角方向ピン間相対変位. を表裏四本の変位計で測定し, 表裏の計測 值を平均した。荷重の計測は,クロスヘッ ド上部のロードセルで行っており, 変位計 およびロードセルは分解能が，それぞれ，0.002 (mm および $8.33(\mathrm{~kg})$ のものを用いた。また，加力方法は， 上下対角方向ピン間相対変位制御とした。各計測器は, 動ひずみ計, A/D 変換器をとおして, また, 加力装置は, D/A 変換器をとおしてコンピュータとつながっており, フィードバック制御システムとなっている。

\section{2 加力装置の制御アルゴリズム}

加力装置の制御およびデータ収録のアルゴリズムを Table 2 に示す。表中, $\tilde{\delta}_{s, i}^{(c)}$ は, 試験体の目標ピン間相 対変位, $\tilde{\delta}_{s, i}^{(m)}$ は, 試験体の計測ピン間相対変位であり, また，下添え字（）的よび（）、は，それぞれ，クロ スヘッド昇降命令時点および計測ピン間相対変位監視時 点のものであることを示している。クロスヘッドの昇降

Table 2 Actuator control and data storage algorithm

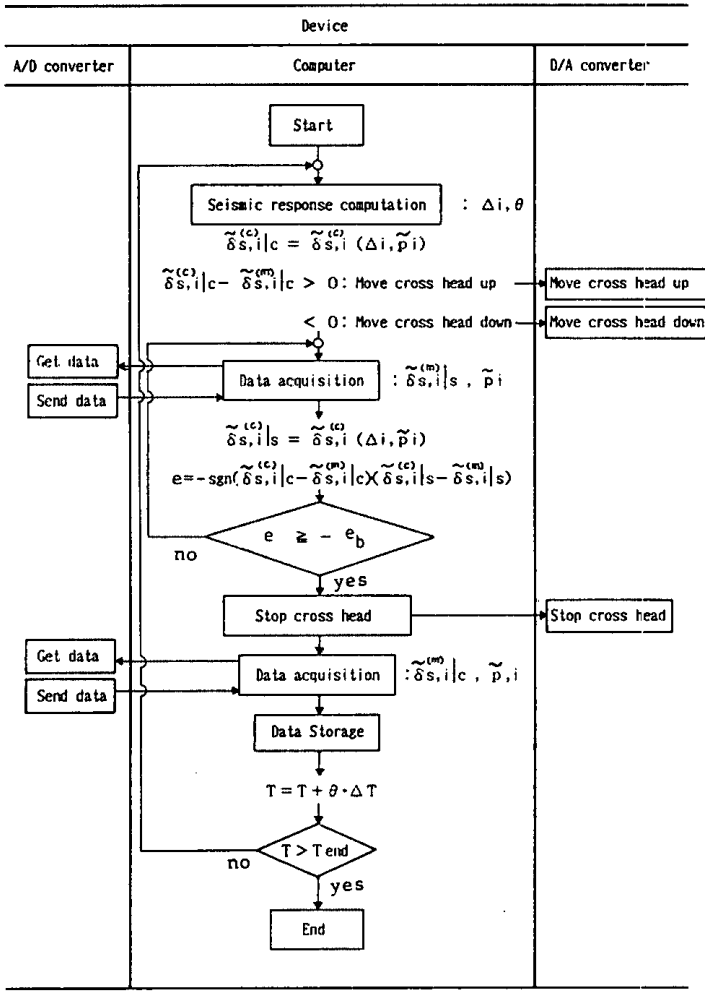




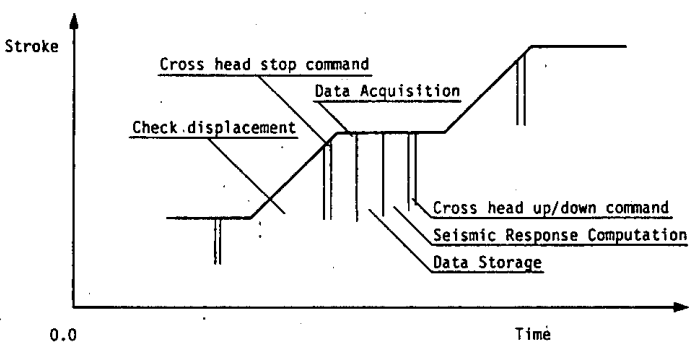

Fig. 5 Timetable of tasks performed in the present test system

条件は次式となる。

$$
\begin{aligned}
& \left.\tilde{\delta}_{s, i}^{(c)}\right|_{c}-\left.\tilde{\delta}_{s, i}^{(m)}\right|_{c}>0 \cdots \text { クロスヘッド上昇 } \\
& \left.\tilde{\delta}_{s, l}^{(c)}\right|_{c}-\left.\tilde{\delta}_{s, i}^{(m)}\right|_{c}<0 \cdots \text { クロスヘッド下降 }
\end{aligned}
$$

一方, 強制変位の完了条件はクロスヘッドの停止命令が 出てから, 実際に停止するまでの若干の遅れを考慮し, 次式とした。

$$
e \geqq-e_{b}
$$

ここに,

$$
e=-\operatorname{sgn}\left(\left.\tilde{\delta}_{s, i}^{(c)}\right|_{c}-\left.\tilde{\delta}_{s, i}^{(m)}\right|_{c}\right) \cdot\left(\left.\tilde{\delta}_{s, i}^{(c)}\right|_{s}-\left.\tilde{\delta}_{s, i}^{(m)}\right|_{s}\right)
$$

\section{sgn：符号関数}

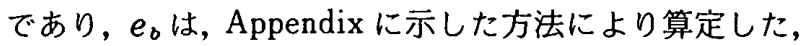
停止命令が出てから実際に停止するまでの間のクロス ヘッドの予想オーバーシュート量礼である。

次に，各作業とクロスヘッドの昇降の関係を Fig. 5 に示す。変位, 荷重等実験データの取得およびその保存, 地震応答量の計算は, クロスヘッドが停止し，一定状態 となった後に行われる。

\section{3 時間積分について}

\section{3.1 時間積分法}

本実験システムでは，(1) 式で与えられる運動方程 式の時間積分法として, 実験剛性を必要としない半陽的 解法であり,また, 復元力特性が軟化する場合にもスキー ムが安定となる，オペレータ・スプリッティング法61.7 を採用する。この時間積分法のアルゴリズムを以下に示 す。

構造物の復元力を，変位に比例する線形部分と履歴の 影響を受ける非線形部分の 2 つの項に分解し，線形項お よび減衰項については無条件安定な平均加速度法を，ま

注 2) オーバーシュート量という語句は，別の意味で使われ ている文献もある8が，本報告では，本文中にも記して あるように，クロスヘッドの停止命令が出てから，実際 に停止するまでのクロスヘッドの移動量をオーバー シュート量, 一方, 運動方程式から求められる停止位置 と実際のそれとの差を位置決め誤差量と呼んでいる。

したがって,クロスヘッドが指定された位置にきた時 にその停止命令を出し，かう3.3.2 項で述べる積分時間 刻みの補正も行わない場合には， オーバーシュート量＝位置決め誤差量
た，非線形項に対しては，条件付き安定となる予測子一 修正子法を用いると, $(\theta \cdot \Delta t)$ 時間後の運動方程式は， 次式のように表される。

$$
\begin{aligned}
& \boldsymbol{m} \cdot \ddot{\boldsymbol{x}}(t+\theta \cdot \Delta t)+\boldsymbol{c} \cdot \dot{\hat{\boldsymbol{x}}}(t+\theta \cdot \Delta t) \\
& \quad+\boldsymbol{k}_{\boldsymbol{l}} \cdot \hat{\boldsymbol{x}}(t+\theta \cdot \Delta t)+\left\langle\boldsymbol{f}\left(\boldsymbol{x}^{*}(t+\theta \cdot \Delta t)\right)\right. \\
& \left.\quad-\boldsymbol{k}_{\boldsymbol{l}} \cdot \boldsymbol{x}^{*}(t+\theta \cdot \Delta t)\right\rangle=-\boldsymbol{m} \cdot \boldsymbol{I} \cdot \ddot{y}(t+\dot{\theta} \cdot \Delta t)
\end{aligned}
$$

$$
\begin{aligned}
& \text { ここに， } \\
& \dot{\hat{x}}(t+\theta \cdot \Delta t)=\dot{x}(t)+\dot{\theta} \cdot \Delta t / 2 \cdot\langle\ddot{x}(t \\
& +\ddot{x}(t+\theta \cdot \Delta t)\rangle \\
& \hat{x}(t+\theta \cdot \Delta t)=x(t)+\theta \cdot \Delta t \cdot \dot{x}(t) \\
& +(\theta \cdot \Delta t)^{2} / 4 \cdot\langle\ddot{x}(t) \\
& +\ddot{x}(t+\theta \cdot \Delta t)\rangle \\
& x^{*}(t+\theta \cdot \Delta t)=\dot{x}(t)+\theta \cdot \Delta t \cdot \dot{x}(t) \\
& +(\theta \cdot \Delta t)^{2} / 4 \cdot \ddot{x}(t)
\end{aligned}
$$

また， $\boldsymbol{k}$ は，構造物の初期弹性剛性マトリックス， $t$ は時刻， $\Delta t$ は積分時間刻みであり， $\theta$ は次項に示す加 力誤差をなくすための積分時間刻みの補正係数である。

(12.a, b) 式を（11）式に代入，整理すると，次式と なる。

$$
\ddot{\boldsymbol{x}}(t+\theta \cdot \Delta t)=\boldsymbol{m}_{\text {ess }}^{-1} \cdot \boldsymbol{f}_{\text {ess }}
$$

ここに,

$$
\begin{aligned}
\boldsymbol{m}_{\text {esf }}= & \boldsymbol{m}+\theta \cdot \Delta t / 2 \cdot \boldsymbol{c}+(\theta \cdot \Delta t)^{2} / \mathbf{4} \cdot \boldsymbol{k}_{\boldsymbol{I}} \cdots(14 . \mathrm{a}) \\
\boldsymbol{f}_{\text {eff }}= & -\boldsymbol{c} \cdot\langle\dot{\boldsymbol{x}}(t)+\theta \cdot \Delta t / 2 \cdot \ddot{\boldsymbol{x}}(x)\rangle \\
& -\boldsymbol{f}\left(x^{*}(t+\theta \cdot \Delta t)\right) \\
& -\boldsymbol{m} \cdot \boldsymbol{I} \cdot \ddot{y}(t+\theta \cdot \Delta t) \cdots \cdots \cdots \cdots \cdots \cdots(14 . \mathrm{b})
\end{aligned}
$$

であり, $f\left(x^{*}(t+\theta \cdot \Delta t)\right)$ の值は, (12.c $)$ 式により 算定される $x^{*}(t+\theta \cdot \Delta t)$ に対して，2.1節および 3.1 節で述べた方法により実験的に求められる。

(13）式により $t+\theta \cdot \Delta t$ における加速度ベクトル : $\ddot{x}$ $(t+\theta \cdot \Delta t)$ が求まり, 速度ベクトル, 変位ベクトルは, 平 均加速度法により算定するものとすると， $\ddot{x}(t+\theta \cdot \Delta t)$ を(12. a, b) 式に代入すれば $\dot{x}(t+\theta \cdot \Delta t), x(t+\theta \cdot \Delta t)$ が定まる。この操作を逐次行うことにより，時刻歴応答 が求まることとなる。

\subsection{2 積分時間刻みの補正}

本実験システムでは，3.2節で述べたように，クロス ヘッドの停止命令が出てから実際に停止するまでの遅れ を考慮して，(9) 式が満足された時，停止命令を出す。 この制御により、試験体に実際に負荷される強制変位量 は，ほぼ（12.c）式から算定される值となる（誤差の平 均值がほぼ0）が, 若干のバラツキが生じることは免れ ない。ところが，本研究で扱うような実験対象が 1 自由 度系の場合には，以下に示すように積分時間刻みを実強 制変位量に対応するように変更することにより，変位が 反転する場合を除いて，この誤差をほぼ完全に補正する ことが可能である。 


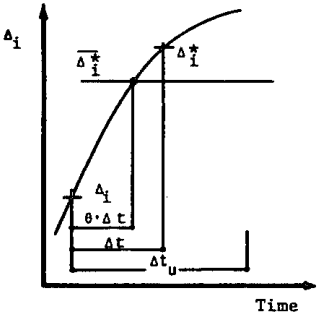

(a)

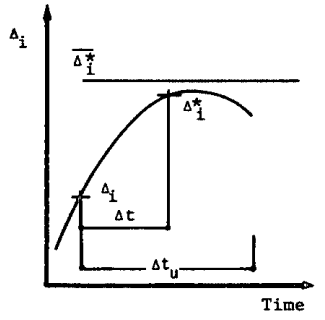

(b)

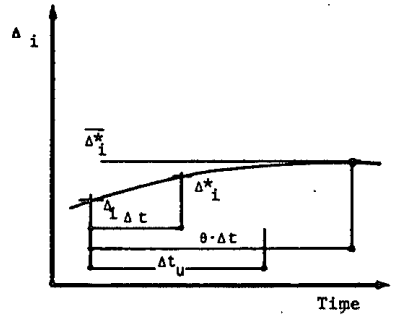

(c)

Fig. 6 Adjustment of time increment by Eqs. (18. a, b)

Table 3 Structural properties of S. D. O.F. systen

\begin{tabular}{|c|c|c|}
\hline$T_{1}(\mathrm{sec})$ & $\mathrm{m}_{1}\left(\mathrm{t} \cdot \mathrm{sec}^{2} \mathrm{~cm}\right.$ & $\mathrm{n}_{\mathrm{d}}$ \\
\hline \hline 0.3640 & 0.7480 & 1.0 \\
\hline$\psi$ (deg.) & $\mathrm{a}_{\mathrm{w}}$ & ${ }_{\mathrm{t}}$ \\
\hline 45.0 & 3.188 & 8.396 \\
\hline$A_{\mathrm{d}, 1}\left(\mathrm{~cm}^{2}\right)$ & $\ell_{\mathrm{d}, \mathrm{i}}(\mathrm{cm})$ & $\mathrm{K}_{\mathrm{f}, 1}(\mathrm{t} / \mathrm{cm})$ \\
\hline \hline 135.48 & 460.14 & 66.87 \\
\hline
\end{tabular}

$\mathrm{T}_{1}:$ Natural period

まず，実験を行う層の目標層間変位： $\Delta_{\imath}^{*}$ を次式によ り求める。

$$
\Delta_{i}^{*}=x_{i}^{*}(t+\Delta t)-x_{i-\mathrm{i}}^{*}(t+\Delta t)
$$

ここに, $x_{i}^{*}(t+\Delta t)$ および $x_{i-1}^{*}(t+\Delta t)$ は, $\theta=1$ と した (12.c) 式により算定される值である。

層間変位が $\Delta_{i}^{*}$ となるよう，(5.a, b)，(6.a, b) 式を 満たしながら試験体に強制変位を加えた後, 実制御層間 変位: $\bar{\Delta}_{i}^{*}$ を計測する。さて, (12.c) 式より, $i$ 層の層 間変位が, $\bar{\Delta}_{i}^{*}$ となるための, 積分時間刻みの補正係数は, 次式から求められる。

$$
\bar{\Delta}_{i}^{*}=\Delta_{i}(t)+\theta \cdot \Delta t \cdot \dot{\Delta}_{i}(t)+(\theta \cdot \Delta t)^{2} / 4 \cdot \ddot{\Delta}_{i}(t)
$$

ここに,

$$
\begin{aligned}
& \Delta_{i}(t)=x_{i}(t)-x_{i-1}(t) \\
& \dot{\Delta}_{i}(t)=\dot{x}_{i}(t)-\dot{x}_{i-1}(t) \\
& \ddot{\Delta}_{i}(t)=\ddot{x}_{i}(t)-\ddot{x}_{i-1}(t)
\end{aligned}
$$

であり， $\theta$ は，前述のように積分時間刻みの補正係数で ある。(16) 式を $\theta$ について解くと,

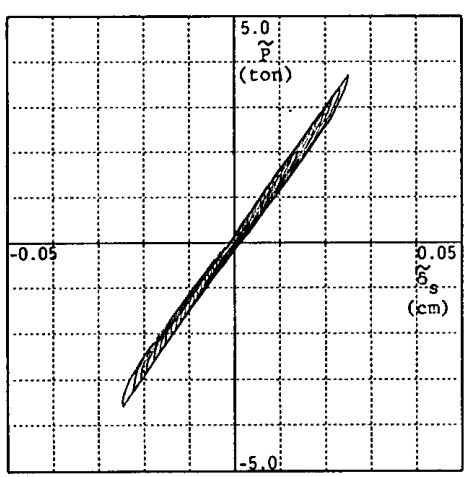

(a) Experimental

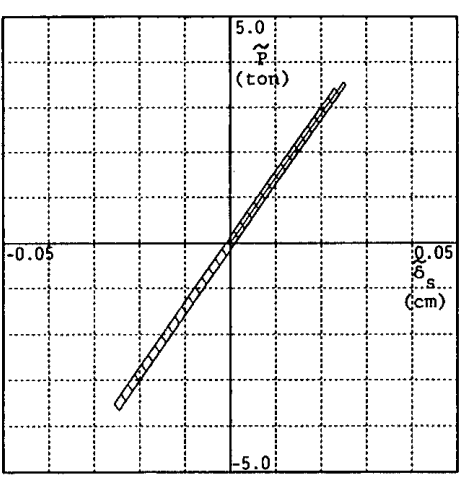

(b) As sumed
Fig.7 $\tilde{P}-\tilde{\delta}_{s}$ relations under free vibration

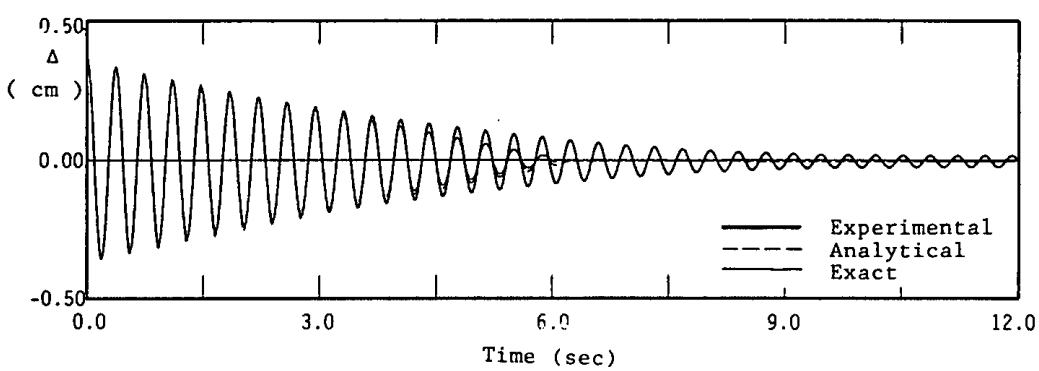

Fig. 8 Time history of inter-story displacement responses under free vibration
$\ddot{\Delta}_{t}(t)=0$ のとき

$$
\theta=\left(\bar{\Delta}_{i}^{*}-\Delta_{i}(t)\right) /\left(\Delta t \cdot \dot{\Delta}_{i}(t)\right)
$$

$\ddot{\Delta}_{i}(t) \neq 0$ のとき

$$
\theta=2 \cdot \frac{-\dot{\Delta}_{i}(t) \pm \sqrt{\dot{\Delta}_{i}^{2}(t)+\left(\bar{\Delta}_{i}^{*}-\Delta_{i}(t)\right) \cdot \ddot{\Delta}_{i}(t)}}{\Delta t \cdot \ddot{\Delta}_{i}(t)}
$$

となる。

$\theta$ が虚恨もしくは, 2 根がともに負のときは, $\theta=1$ とし, 2 つの正根を持つ時は, 小さい方の値を選ぶ (Fig. 6 (a)，(b) 参照)。また，時間積分に関する精度の悪化を 防ぐため, Fig. 6(c) に示すように, $\theta \cdot \Delta t$ が前もって 決められた積分時間増分の上限值 : $\Delta t_{u}$ を越えるよう な場合は， $\theta=1$ とする。

実験における制御点が一つの場合には，ここに示した ように, 積分時間刻みを調整し, 制御点の強制変位量に 対応した時刻で運動法方程式をたてることにより，加力 誤差を解消することが出来る。

\section{4. 実験精度の検証}

2 節および 3 節では, 制振装䩤を有す るブレース付架構のオンライン・コン ピュー夕制御実験法について述べ，この 実験の精度上最も重要な, 武験機の位員 決め誤差の制御および修正法を示した。 本節では，本実験システムの精陪を検証 するために, Table 3 に示すような構造 特性を有する 1 自由度系について，自由 振動実験, 正弦波振動実験, 弾性実地祳 応答実験を行った結果について報告す る。

\section{1 自由振動実験}

まず，積分時間刻み： $\Delta t$ を $1 /(20 \cdot \omega)$ ， 積分時間刻みの上限値 $: \Delta t_{u}$ を $2 \cdot \Delta t$, 試験機のストローク速度： $v_{s}$ を 1.17 $(\mathrm{mm} / \mathrm{min}), \quad ゙ ー$ 夕取得に要する時間 $: T_{s}$ を $0.1443(\mathrm{sec})$, 減衰定数 $: h$ 学 0.0 として, $0.40(\mathrm{~cm})$ の初期層間変 位を与えた時の自由振動実験を行い，皦

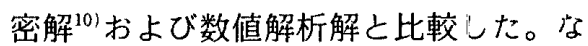


お，本節および次節に示す数値解析解に おける時間積分は, 積分時間刻みを実験 に用いた刻みの $1 / 10$ とした平均加速度 法を用いて行っている。Fig. 7 は荷重： $\tilde{P}$-ピン間相対変位: $\tilde{\delta}_{s}$ 関係を, また, Fig. 8 は層間変位応答： $\Delta$ の時刻歴応答 を示したものであり, 図中, 太実線, 破 線および細実線は，それぞれ，実験結果，

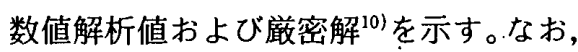
Fig.7（a）からわかるように，実験荷重 には摩擦力が含まれるので, 数值解析解

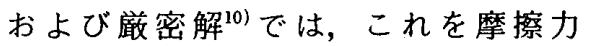
$0.120(\mathrm{t})$ のクーロン摩擦として Fig.7 (b) のように評価している。これらの 図より，4.0(sec) 付近までは, 実験值 は, 厳密解 ${ }^{10)}$, 数值解析解之よく一致し ているが，それ以降では実験值の振幅が 大きくなっていることがわかる。これは， 振幅が小さくなると, 実験荷重の摩擦力 が次第に小さくなる傾向にあるためであ る。一方, 厳密解と数値解析解は全時刻 を通じてよく一致しており, 以下の実験 では, この摩擦力を考慮した数值解析解 を実験精度の比較対照用として用いるこ とにする。

\section{2 正弦波振動実験}

次に, 積分時間刻み: $\Delta t$ を $1 /(20 \cdot \omega)$, その上限值： $\Delta t_{u}$ を $2 \cdot \Delta t$, 減衰定数：

$h$ を 0.02 , さらに，試験機のストローク速度： $v_{s}$ を $2.35(\mathrm{~mm} / \mathrm{min})$, デー夕取得に要する時間： $T_{s}$ を $0.1443(\mathrm{sec})$ とし, 変位, 速度ともに 0 の状態から定 常状態に至るまでの正弦波振動実験を行った。この正弦 波振動実験では，3.2 節および 3.3 節で述べた制御アル ゴリズムおよび積分時間刻みの補正による効果を見るた め, 入力正弦波の振動数： $\omega_{0}$ を, 位置決め誤差の応答 に及ぼす影響が最も大きく出ると考えられる共振振動数 付近にとり，これ等の位置決め誤差を無くすための操作 を全く施さない場合についても実験を行っている。その 代表的結果を数值解析解とともに Fig. 9, 10 および Table 4 に示す。Fig. 9 および 10 は，入力正弦波の振 動数： $\omega_{0}$ を系の固有振動数： $\omega$ に一致させた時の層間 変位応答の時刻歴および位置決め誤差量： $e$ の時刻歴 を，位置決め誤差量を無くすための操作を施した場合と 施さない場合について比較したものであり，また， Table 4 には, 入力正弦波の振動数： $\omega_{0}$ を 18.76 , $17.95,17.26,16.53,15.70$ と変化させた時の定常時の 層間変位応答倍率を，位置決め誤差を無くすための操作 を施した場合について示している。なお，表中の $\Delta_{s t}$ は，
Table 4 Magnification factors of displacement response

\begin{tabular}{|c|c|c|c|c|c|}
\hline$\because$ & $\sigma$ & $\oplus$ & $\frac{\Delta_{\text {anal }}}{\Delta}$ & $\frac{\Delta_{\text {exp }}}{\Delta_{\text {st }}}$ & $\frac{\Delta_{\text {exp }}}{\Delta_{\text {ana1 }}}$ \\
\hline 18.76 & 15.109 & 1.0973 & $i .683$ & 4.755 & 1.0154 \\
\hline 17.95 & 9.930 & 1.0497 & 8.286 & 8.350 & 1.0077 \\
\hline 17.26 & 4.339 & 1.0088 & 15.623 & 15.919 & 1.0190 \\
\hline 16.33 & 9.864 & 0.9711 & 11.464 & $11: 805$ & 1.0298 \\
\hline 15.70 & 14.297 & 0.9198 & 6.105 & 6.38 & 1.0219 \\
\hline
\end{tabular}

a : dcceralation applitude $\Delta_{s t}=a / o^{2}$ : Static response.

次式で表される静的層間変位である。

$$
\Delta_{s t}=\alpha / \omega^{2} \cdots
$$

ここに, $\alpha$ :入力加速度振幅

$\omega:$ 系の固有振動数

これ等の結果より（（9) 式が満足された時クロスヘッ ドの停止命令を出し，さらに，(18. a, b) 式により積分 時間刻みの補正を行えば，実験値は，数値解析解之良好 に一致し，また，位置決め誤差も，前述のように，変位 の反転時以外生じないことがわかる。

4.3 弾性地震応答実験

実験精度検証の最後の例題として，前出と同様の 1 自 
由度系について, 正弦波の足し合わせと 考えられる地震加速度波に対する弾性応 答実験を行った。入力地震波をエルセン 卜口 NS 波（最大入力加速度: $A_{\max }=$ $40.0 \mathrm{gal})$ とし，積分時間刻み： $\Delta t$ を 系の固有周期の約 $1 / 35$ である 0.01 $(\mathrm{sec})$, 積分時間刻みの上限值: $\Delta t_{u}$ を $0.02(\mathrm{sec})$, 減衰定数 $: h$ を 0.02 , 試 験機のストローク速度： $v_{s}$ を 2.35 $(\mathrm{mm} / \mathrm{min})$, データ取得に要する時間 $: T_{s}$ を $0.1443(\mathrm{sec})$ として実験を行っ た。Fig. 11 に層間変位応答の時刻歴を 数値解析解とともに示す。この図より, 実験值は, 数値解析解亡よく一致してお り，実地震波に対しても本実験精度は十 分良好であることがわかる。

\section{5. 弾塑性地震応答実験と数值復元力} モデルの精度の検証

前節での弾性応答実験により，本実験 システムの精度が十分高いことが示され た。そこで, 本節では, 1 自由度系の弾 塑性地震応答夷験を行い,その結果を基 に，2.2 節で誘導した制振装置の Bilinear 型および Ramberg-Osgood 型復 元力モデルの精度, 有用性を検討する。 前節と同じ Table 3 の構造特性を持つ 1 自由度系について, 入力地震波をエルセ ントロ NS 波（最大入力加速度： $A_{\max }$ $=300 \mathrm{gal})$, タフト $\mathrm{EW}$ 波 $\left(A_{\max }=270\right.$ gal) および八戸NS 波 $\left(A_{\max }=250 \mathrm{gal}\right)$ とした 3 ケースについての地震応答実験 を行った。なお，積分時間刻み，その上 限値等の条件は，4.3 節と同様とし，ま た，履歴減衰装置の有孔鋼板はHT 60 の鋼材のものを用いた。

Fig. 12(a)〜 (c) は, エルセントロ $\mathrm{NS}$ 波，タフト $\mathrm{EW}$ 波および八戸 NS 波 を入力した時の層間変位応答時刻歴を，

実験値を実線で，Bi-linear 型および Ramberg-Osgood 型復元力モデルを用 いた数値解析解を破線および点線で，そ れぞれ，示す。また，Fig.13には，工 ルセントロ NS 波を入力したときの荷重 : $\tilde{P}$-ピン間相対変位: $\tilde{\delta}_{s}$ の関係を実験值を (a), Bilinear 型および Ramberg-Osgood 型復元力モデルを用 いた場合の解析值を，それぞれ，(b) および (c)に示 している。さらに, Table 5 には, 応答量のうち, 工学 的見地から重要と思われる最大ピン間相対変位量：

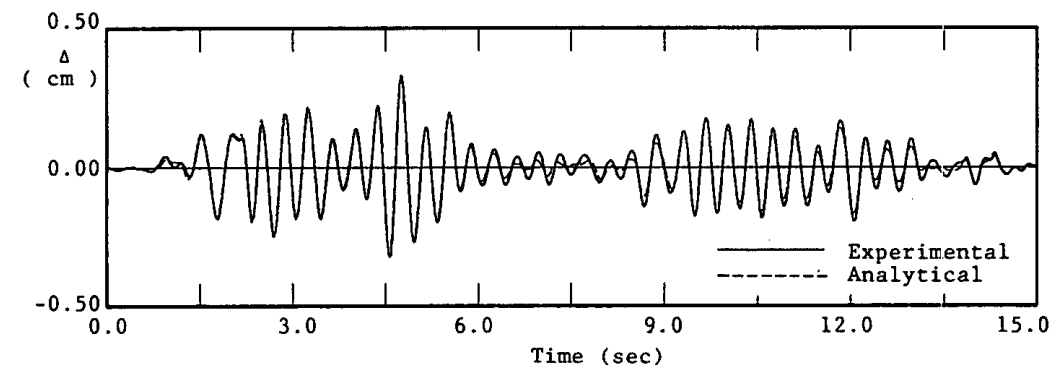

Fig. 11 Seismic responses of linear S. D. O.F. system to EL CENTRO NS earthquake $\left(A_{\max }=40.0 \mathrm{gal}\right)$

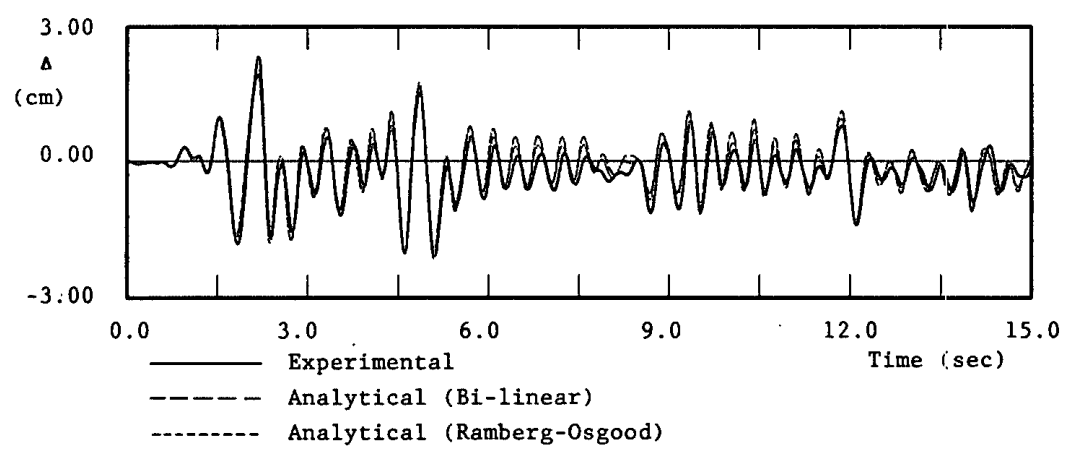

Fig. 12(a) Seismic responses of non-linear S. D. O.F. system to EL CENTRO NS earthquake $\left(A_{\max }=300.0 \mathrm{gal}\right)$

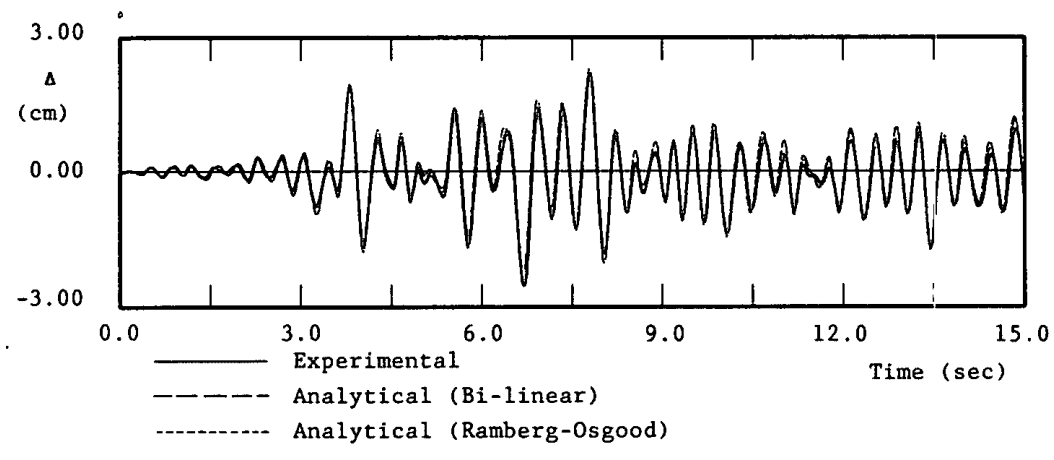

Fig. 12(b) Seismic responses of non-linear S. D. O.F. system to TAFT EW earthquake $\left(A_{\max }=270.0 \mathrm{gal}\right)$

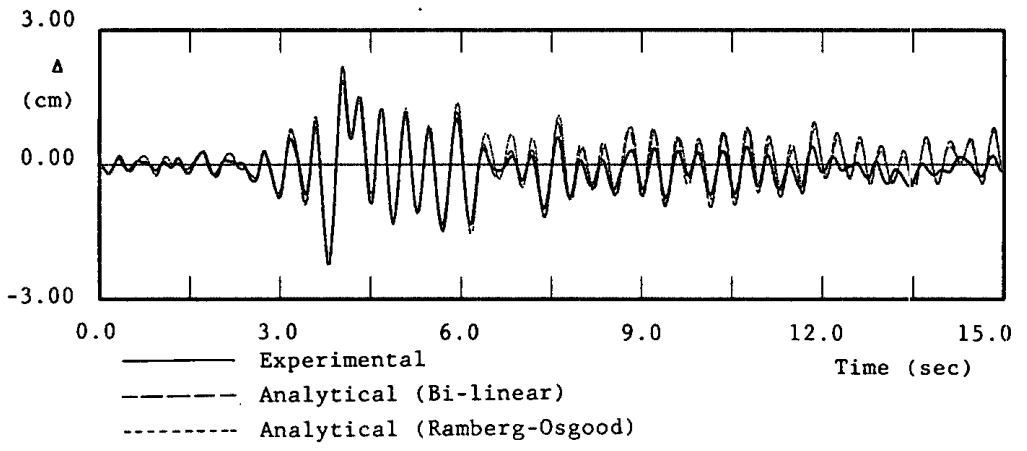

Fig. 12(c) Seismic responses of non-linear S.D. O.F. system to HACHINOHE NS earthquake ( $A_{\mathrm{max}}=250.0 \mathrm{gal}$ )

$\tilde{\delta}_{\text {smax }}$ と, 履歴吸収エネルギー量：Wo $W_{p}$ ○つの地震波 について示す。これらの結果から, 数値解析值は, 最大 ピン間変位量が，実験値に比べ若干ばらついた值を示す が，層間変位応答時刻歴および履歴吸収エネルギーは, ほぼ一致しており，2.2 節に示した復元力モデルを用い 


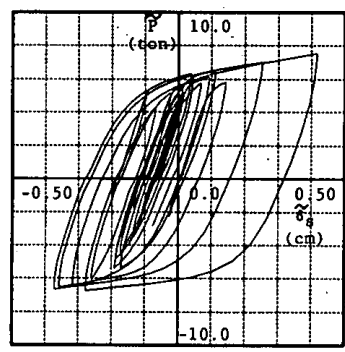

(a) Experimental

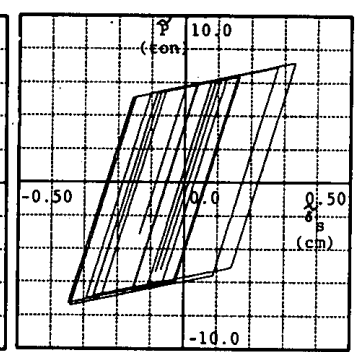

(b) Analytical (Bi-linear)

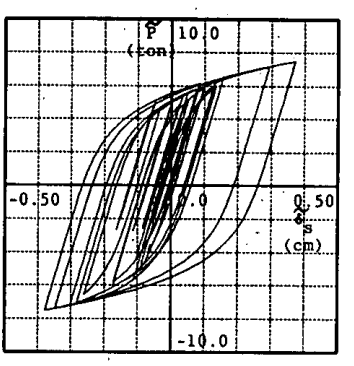

(c) Analytical (Ramberg-0sgood)

Fig. $13 \tilde{P}-\tilde{\delta}_{s}$ relations in seismic response to EL CENTRO NS earthquake $\left(\dot{A}_{\max }=300.0 \mathrm{gal}\right)$

Table 5 Comparison between analytical and experimental responses

\begin{tabular}{|c|c|c|c|c|}
\hline & & $\begin{array}{r}\text { Analytical } \\
\text { Bi-I Inear }\end{array}$ & $\begin{array}{c}\text { Analytical } \\
\text { Ramberg-0ssood }\end{array}$ & Exper imental \\
\hline \multirow{2}{*}{$\begin{array}{c}\text { Ei CENTRO } \\
\text { NS }\end{array}$} & $\begin{array}{l}\widetilde{\delta}_{\text {smax }} \\
(\mathrm{cm})\end{array}$ & $\left(\begin{array}{l}0.346 \\
0.830\end{array}\right)$ & $\begin{array}{l}0.379 \\
(0.909)\end{array}$ & 0.417 \\
\hline & $\left(\begin{array}{c}w_{p} \\
c m\end{array}\right)$ & $\begin{array}{c}20.34 \\
(0.911)\end{array}$ & $\begin{array}{c}20.78 \\
(0.931)\end{array}$ & 22.33 \\
\hline \multirow{2}{*}{$\begin{array}{l}\text { TAFT } \\
\text { EV }\end{array}$} & $\begin{array}{c}\widetilde{\delta}_{\text {smax }} \\
(\mathrm{cm})\end{array}$ & $\begin{array}{c}0.392 \\
(0.836)\end{array}$ & $\begin{array}{c}0.455 \\
(0.970)\end{array}$ & 0.469 \\
\hline & $\left(\begin{array}{c}W \\
(t \cdot c m\end{array}\right)$ & $\left(\begin{array}{l}33.06 \\
(0.954)\end{array}\right.$ & $\left(\begin{array}{l}35.15 \\
(1.015\end{array}\right)$ & 34.64 \\
\hline \multirow{2}{*}{$\begin{array}{c}\text { HACHINOHE } \\
\text { NS }\end{array}$} & $\widetilde{\delta}_{\text {smax }}(\mathrm{cm})$ & $\begin{array}{l}0.406 \\
(1.097)\end{array}$ & $\begin{array}{l}0.386 \\
(1.043)\end{array}$ & 0.370 \\
\hline & $\left(\begin{array}{c}\mathrm{W}_{\mathrm{p}} \\
(\tau \cdot \mathrm{cm})\end{array}\right.$ & $\begin{array}{l}16.72 \\
(0.982)\end{array}$ & $\left(\begin{array}{l}18.63 \\
(1.095)\end{array}\right.$ & 17.02 \\
\hline
\end{tabular}

Values in parentheses : Ratios to experimental responses.

た地震応答解析の応答予測が妥当なものであること，ま た, Ramberg-Osgood 型復元力モデルによる応答と Bilinear 型復元力モデルによるそれとの間には大きな差は ないことがわかる。

\section{6.むむび}

本報告では，オンライン・コンピュータ制御実験の， 制振装置を有するブレース付架構への適用法について述 べるとともに，本実験精度上最も重要な試験機の位置決 め誤差を解消する 1 つの方法の提案を行い，この手法を 組み込んだ本実験システムの精度が，十分良好であるこ とをいくつかの弾性振動実験により明らかにした。また， 履歴減哀装置を，漸増振幅試験結果を基に; Bi-linear 型および Ramberg-Osgood 型の $2 つ$ 数值モデルに置 換し，その弾塑性地震応答性状をオンライン・コン ピュー夕制御実験結果と比較することにより，復元力モ デルの精度，有用性を明らかにした。

次報以後で,このオンライン・コンピュータ制御実験 システムを用いて，本制振装置を有する 7 層鉄骨建物の 弾塑性実地震応答実験を行い，制振装置の実地震応答時 におけるエネルギー吸収性能，非定常振幅疲労特性を明 らかにするとともに，実地震時の制振装置の累積損傷値 等を報告する。

\section{謝 辞}

本研究に当たり; 広島大学, 学生, 中村佳也（現, フ ジ夕工業), 西山正三, 才門章彦, 倉本清嘼 (現, 鹿島
建設）の諸兄には，実験実施，資料整理に多大な協力を 得ましたことに感謝します。また，東京大学生産技術研 究所 高梨晃一教授, 神戸大学工学部 中島正愛助教授に は貴重な助言を頂きました。ここに記して謝意を表しま す。

\section{参考文献}

1）玉井宏章，近藤一夫，花井正実：ブレース付架構制振装 置に関する研究 その 1 履歴減衰装置の復元力特性, 日本建築学会構造系論文報告集, 第 387 号, pp. 24-34, 昭和 63 年.

2）玉井宏章，近藤一夫，花井正実：ブレース付架構制振装 置に関する研究 その 2 棈円孔を有する有孔鋼板の工 ネルギー吸収能力について, 日本建築学会構造系論文報 告集, 第 401 号, pp. 139-149, 平成元年.

3）西山正三, 王井宏章, 中村住也, 近藤一夫, 花井正実： ブレース付架構制振装置のオンライン・コンピュータ制 御実験 その 1 システムの概要とその精度について, 日本建築学会中国支部研究報告集, 第 15 巻, pp. 41-44, 平成元年.

4）玉井宏章, 中村佳也, 西山正三, 近藤一夫, 花井正実： ブレース付架構制振装置のオンライン・コンピュータ制 御実験 その 2 地震応答実験，日本建築学会中国支部 研究報告集, 第 15 巻, pp. 45-48, 平成元年.

5）高梨晃一, 宇田川邦明, 関松太郎, 岡田恒男, 田中 尚 : 電算機一試験機オンラインシステムによる構造物の非 線形地震応答解析 (その 1 システムの内容)：日本建築 学会論文報告集, 第 229 号, pp. 77-83, 昭和 50 年.

6) M.E. Plesha, T. Belytschko: A Constitutive Operator Splitting Method for Nonlinear Transient Analysis, Computers and Structures, Vol.20, No.4, pp.767-777, 1985.

7）石田雅利, 中島正愛, 上之薗隆志, 堤 英明：サブス卜 ラクチャ法を用いた仮動的実験（その 2 オペレータス プリッティシグ法の適用性）：日本建築学会大会学術講演 梗概集, pp. 181-182, 昭和 63 年.

8) M. Nakashima, H. Kato : Experimental Error Growth in Pseudo-Dynamic Testing (Stability and Accuracy Behavior of Pseudo-Dynamic Response : Part 3), Journal of Structural and Construction Engineering, Transactions of AIJ, No. 386, pp. 36-48, 1988.

9) ' P.C. Jennigs : Earthquake Response of a Yielding Structure, Proc. of ASCE, Vol.90, No. EM4, pp.4168,1964 
Table A-1 Statistical characteristic values of over-shoot varied with the values of $V_{s}$ and $T_{s}$ under no correction

\begin{tabular}{|c|c|c|c|c|c|}
\hline $\begin{array}{c}\mathrm{V}_{\mathrm{s}} \\
(\mathrm{mm} / \mathrm{min})\end{array}$ & $\begin{array}{c}\mathrm{T}_{\mathrm{s}} \\
(\mathrm{sec})\end{array}$ & $\mathrm{c}_{\mathrm{p}}$ & $\mathrm{c}_{\mathrm{m}}$ & $\begin{array}{c}\overline{\mathrm{e}} \\
(\mathrm{cm})\end{array}$ & $\begin{array}{c}\mathrm{\sigma}_{\mathrm{e}} \\
(\mathrm{cm})\end{array}$ \\
\hline 1.17 & 0.1443 & 1.658 & 0.504 & 0.000467 & 0.000298 \\
\hline 2.35 & 0.1443 & 1.598 & 0.570 & 0.000903 & 0.000479 \\
\hline 4.70 & 0.1443 & 1.459 & 0.574 & 0.001650 & 0.000900 \\
\hline 2.35 & 0.1312 & 1.729 & 0.560 & 0.000889 & 0.000493 \\
\hline 2.35 & 0.4629 & 1.437 & 0.620 & 0.002608 & 0.001231 \\
\hline
\end{tabular}

10） L. Meirovitch : 電子計算機活用のための振動解析の理 論と応用 $<$ 上, 丸善, pp. 21-24, 昭和 59 年.

\section{Appendix 試験機の制御能力について}

クロスヘッドに対する停止命令が出てから実際にクロスヘッ ドが停止するまでの間には若干の遅れがあるため,クロスヘッ ドが指定した位置に達した時にその停止命令を出したのでは, 指定した停止位置と実際のそれとの間には誤差が生じる。本研 究でオーバーシュート量と呼んでいるこの誤差量の特性を把握 するために, Table 3 に示す構造特性を有する一質点系の正弦 波応答実験を行った。試験機のクロスヘッドのストローク速度 $: V_{s}$ およびデー夕取得に要する時間： $T_{s}$ を様々に変え, 次式 で定義したオーバーシュート量の分布を表すパラメータ值を, オーバーシュート量の平均值 : $\bar{e}$ および標準偏差值 : $\sigma_{e}$ ととも に Table A-1 に示す。

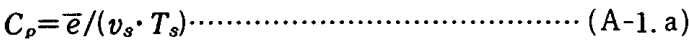

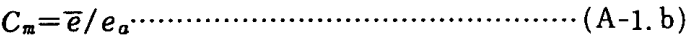

ここに,

$\bar{e}:$ オーバーシュート量の平均值

$T_{s}:$ デー夕取得に要する時間

$v_{s}:$ 試験機のストローク速度

$e_{a}:$ オーバーシュート量の集合の $95 \%$ を含む誤差幅

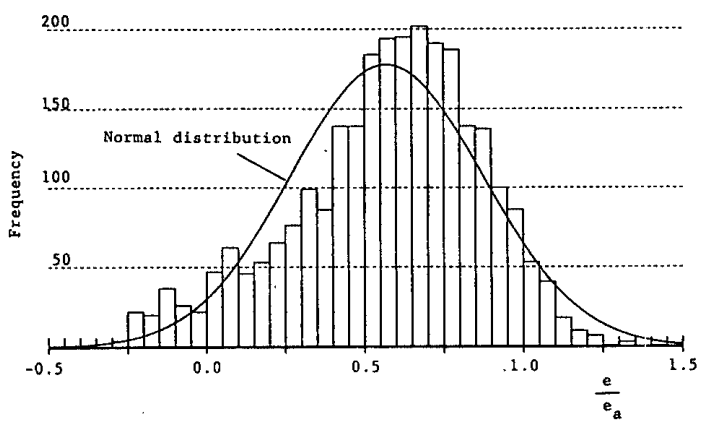

Fig. A-1 Frequency distribution of over-shoot under no correction

また，オーバーシュート量の頻度分布を正規分布とともに Fig. A-1 に示す主3)。これらの結果から， $C_{p}, C_{m}$ 値とも， $V_{s}$, $T_{s}$ に対する依存性は小さく，ほぼ一定とみなせること，また， オーバーシュート量の分布性状は正規分布に近いことがわかる。 本実験システムでは，試験機の予測オーバーシュート量： $\epsilon_{b}$ をTable A-1 に示した $C_{p}$ の平均値を用いて,

$$
e_{0}=C_{p} \cdot v_{s} \cdot T_{s}
$$

で評価し，この予想オーバーシュート量に見合う分だけ早めに クロスヘッドの停止命合を出している (本文 (9.a, b) 式参照)。 この操作により，クロスヘッドの実際の停止位置を，位置決め 誤差の平均值がほぼ 0 となるよう，指定された位置周辺にばら つかせることが可能である。

注 3）本実験システムで制御する変位は履歴诚衰装置のピン 間相対変位であり，これは，(6.a) 式に示すように，運 動方程式から定められる層間変位のブレース方向成分か らブレースの伸びを差し引いた形で与えられる。した がってクロスヘッドの指定停止位置は，ブレースの伸び の分だけ加力前後で変化する。このため, Fig. A-1に示 すように,オーバーシュート量は常に正とはならないが， その影響は,オーバーシュート量全体からみれば小さい。

(1989 年 10 月 2 日原稿受理, 1990 年 2 月 16 日採用決定) 